\title{
PENINGKATAN KOMPETENSI PROFESIONAL GURU EKONOMI MELALUI SEKOLAH PASAR MODAL
}

\author{
M. Anas ${ }^{1}$, Mochamad Muchson ${ }^{2}$, Sugiono $^{3}$, Subagyo $^{4}$, Rr. Forijati $^{5}$, Nurin Eva Yanti $^{6}$ \\ 1,2,3,4,5,6 Universitas Nusantara PGRI Kediri, Kediri, Indonesia \\ email: anas@unpkediri.ac.id
}

\begin{abstract}
The purpose of this Capital Market School (SPM) Community Service (PkM) activity is to increase the professional competence of economics teachers in Kediri. The increase in professional competence will have an impact on increasing the ability of economics teachers in: a) development of teaching materials, b) development of learning models, c) development of learning media, d) preparation of assessments, and e) providing empirical experience related to trade mechanisms (transactions) in Indonesia Stock Exchange (IDX). The methods used in this activity are: Test (pre-test and post-test), capital market education (tutorial), and capital market trading practices. Based on data analysis, it can be concluded that this activity is effective because it can improve the professional competence of economics teachers. The indicators for the increase in professional competence are evidenced by the achievement of participant scores as follows: 1) The average score achieved by PSM activity participants after participating in the activity increased to 87.55 compared to before participating in the activity, which was 65.32. 2) Before participating in the activity, the lowest score of participants was 45 and after participating in the activity the lowest score obtained by participants was 75, and 3) the maximum score after participating in the activity was 100 , whereas before the activity the maximum score achieved by participants was 80 .
\end{abstract}

Keywords: Competence Of Teachers, Professionals, Training, Capital Market Schools

\begin{abstract}
Abstrak: Tujuan kegiatan Pengabdian kepada Masyarakat (PkM) Sekolah Pasar Modal (SPM) ini adalah meningkatnya kompetensi profesional guru ekonomi di Kediri. Peningkatan kompetensi professional tersebut akan berdampak kepada meningkatnya kemampuan guru ekonomi dalam: a) pengembangan materi ajar, b) pengembangan model pembelajaran, c) pengembangan media pembelajaran, d) penyusunan asesmen, dan e) memberikan pengalaman empiris terkait dengan mekanisme perdagangan (transaksi) di pasar modal. Metode yang digunakan pada kegiatan ini berupa: Test (pre-test dan post-test), edukasi pasar modal (tutorial), dan praktik perdagangan pasar modal. Berdasarkan analisis data dapat disimpulkan bahwa kegiatan ini efektif karena dapat meningkatkan kompetensi profesional guru ekonomi. Indikator kenaikan kompetensi profesional tersebut dibuktikan dengan capaian nilai peserta sebagai berikut: 1) Nilai rata-rata yang dicapai oleh peserta kegiatan PSM setelah mengikuti kegiatan meningkat menjadi 87,55 dibandingkan dengan sebelum mengikuti kegiatan yaitu sebesar 65,32. 2) Sebelum mengikuti kegiatan nilai terendah peserta adalah 45 dan setelah mengkuti kegiatan nilai terendah yang diperoleh peserta sebesar 75, dan 3) Nilai maksimal setelah mengikuti kegiatan mencapai angka 100, padahal sebelum dilaksanakan kegiatan nilai maksimum yang dicapai peserta sebesar 80 .
\end{abstract}

Kata Kunci: Kompetensi Guru, Profesional, Pelatihan, Sekolah Pasar Modal

\section{Pendahuluan}

Pasar Modal merupakan salah satu materi yang harus dikuasai oleh siswa kelas XI pada pelajaran ekonomi. Rumusan kompetensi dasar pada materi pasar modal ini meliputi: 1) mendeskripsikan pasar modal dalam perekonomian, dan 2) menyimulasikan mekanisme perdagangan saham dan investasi di pasar modal. Kompetensi dasar pertama mengharuskan guru dan siswa memiliki pengetahuan dan pemahaman yang memadai (kognitif) terkait pasar modal, sedangkan kompetensi dasar kedua menekankan agar guru 
dan siswa memiliki pegalaman empirik berkenaan dengan mekanisme perdagangan (transaksi) saham dan investasi lainnya di pasar modal.

Sebagai seorang profesional, guru dituntut untuk memiliki dan meningkatkan kompetensinya dalam rangka meningkatkan kualitas pembelajaran di sekolah (Pemerintah RI, n.d.). Salah satu kompetensi yang harus dikembangkan adalah kompetensi pedagogik. Selain secara inovatif guru dituntut untuk mengambangkan model dan strategi (Rakib, 2016), guru juga selayaknya meng-update dan meng-upgrade pengetahuan dan keterampilannya agar penguasaan materi terkait dengan suatu pelajaran yang diberikan kepada siswa menjadi lebih berkualitas (Kemendikbud, 2017).

Hasil survey yang dilakukan terhadap 136 guru ekonomi SMA/MA di Kediri dan sekitarnya menunjukkan bahwa terdapat beberapa masalah yang terjadi pada guru-guru ekonomi, yaitu: sebagian besar guru ekonomi yang memberikan materi pelajaran pasar modal di SMA/MA menyatakan kurang bisa mengembangkan materi pelajaran secara memadai akibat kurangnya literasi yang dimiliki baik berupa pengetahuan dan pemahaman serta pengalaman empiris terkait mekanisme perdagangan saham di pasar modal. Hal ini ditunjukkan bahwa sebanyak $67,6 \%$ responden merasa lietrasi pasar modal yang dimiliki masih minim. Minimnya literasi pasar modal tersebut antara lain disebabkan karena guru-guru ekonomi yang menjadi responden sebagian besar $(61,8 \%)$ menyatakan belum pernah memiliki pengalaman mengikuti pelatihan pasar modal.

Kondisi demikian mendorong MGMP Ekonomi Kota dan Kabupaten Kediri berkolaborasi dengan Prodi MPE UNP Kediri melakukan kegiatan Pengabdian kepada Masyarakat (PkM) dalam bentuk Sekolah Pasar Modal (SPM) bagi guru-guru ekonomi di wilayah Kediri dan sekitarnya. Kegiatan ini diselenggarakan sebagai implementasi dari visi dan misi Prodi MPE yaitu menghasilkan sumberdaya manusia unggul dalam bidang pendidikan ekonomi.

Kegiatan PkM SPM ini diharapkan dapat mencapai tujuan: 1) meningkatkan literasi pasar modal bagi guru ekonomi, dan 2) memberikan pengalaman empiris bagi guru ekonomi dalam bertransaksi di pasar modal (Bursa Efek Indonesia/BEI). Peningkatan literasi ini penting bagi guru dalam pengembangan kompetensinya, terutama kompetensi profesional berupa penguasaan dan pemahaman akan materi pelajaran yang akan diberikan kepada siswa. Dengan penguasaan pengetahuan dan pemahaman yang memadai terkait pasar modal, maka akan berdampak pula pada: a) meningkatkan kemampuan guru dalam pengembangan materi ajar, b) pengembangan model pembelajaran ekonomi, c) pengembangan media pembelajaran, dan d) pengembangan asesmen dalam pelajaran ekonomi.

Beberapa penelitian dan kegiatan pengabdian kepada masyarakat berupa pendidikan dan pelatihan pasar modal telah beberapa kali dilaksankan oleh beberapa pihak sebelumnya sebagaimana dilakukan oleh Mubarok, F. K. (2018); Prayoga, Y. (2019); Septiani, D. et. al,. (2020); dan Fatimah (2020). Berbeda dengan penelitian dan pengabdian kepada masyarakat terdahulu, kegiatan PkM SMP ini dilakukan dengan metode praktik langsung pasar modal. Kegiatan praktik ini berupa pembukaan rekening dana nasabah oleh setiap peserta dan praktik transaksi jual-beli saham di Bursa Efek 
Indonesia. Dengan praktik pasar modal ini guru ekonomi sebagai peserta SPM memiliki pengalaman empiris bertransaksi jual-beli saham, sehingga pengetahuan, pemahaman dan keterampilan guru ekonomi terkait pasar modal meningkat dengan baik.

\section{Metode}

Pemecahan masalah terkait dengan problematika yang dihadapi oleh guru ekonomi dalam pembelajaran terkait meteri pasar modal sebagaimana telah dipaparkan sebelumnya adalah dengan memberikan pendidikan dan pelatihan. Bentuk pendidikan pelatihan tersebut dikemas dalam bentuk Sekolah Pasar Modal (SPM) sehingga komptenesi yang dimiliki oleh guru ekonomi menjadi semakin memadai. Kompetensi merupakan karekteristik yang mendasari seseorang individu dalam pencapaian kinerjanya secara efektif (Spenser, L. M., \& Spenser, 1993). Definisi tersebut bermakna bahwa kompetensi merupakan bagian kepribadian yang melekat pada seorang individu sekaligus merupakan perilaku yang dapat diprediksi pada segala situsi dan kondisi tugas pekerjaannya (Boyatzis, 2008). Selanjutnya Spencer menyatakan bahwa kompetensi dapat dikategorikan menjadi dua kategori, yaitu theshhold dan differentiating. Theshhold competencies merupakan karakteristik utama, berupa misalnya, pengetahuan, keahlian dasar berupa kemampuan membaca yang harus dimiliki oleh individu agar dapat melaksanakan tugas-tugas pekerjaannya. Differentiating competencies merupakan faktorfaktor pembeda antara satu individu dengan individu lainnya terkait kinerja yang telah dicapai, apakah berkinerja tinggi atau rendah.

Berdasarkan konsep kompetensi sebagaimana dikemukakan oleh Spencer tersebut dapat diidentifikasikan bahwa kompetensi: 1) merupakan kemampuan atau keahlian yang dimiliki oleh individu dalam bidang pekerjaan yang ditekuninya secara resmi, 2) diperoleh dalam jangka waktu tertentu, dan 3) diimplementasikan dalam bentuk sikap dan nilai keseharian dalam melaksanakan tugas.

Berdasarkan Peraturan Pemerintah Nomor 16 Tahun 2005 tentang Standar Nasional Pendidikan dinyatakan bahwa kompetensi guru terdiri atas empat kompetensi, yaitu kompetensi pedagodik, kompetensi kepribadian, kompetensi sosial, dan kompetensi profesional. Kompetensi pedagogik berkaitan dengan kemampuan yang harus dimiliki oleh guru dalam pengelolaan pembelajaran (peserta didik), kompetensi kepribadian merupakan kemampuan yang melekat pada diri pribadi seorang guru, kompetensi sosial adalah seorang guru dalam berinteraksi dengan masyarakat, dan kompetensi profesional merupakan kemampuan yang harus dimiliki oleh seorang guru dalam penguasaan materi pembelajaran secara luas dan mendalam.

Penguasaan materi pembelajaran secara luas dan mendalam akan memudahkan guru untuk mengintegrasikan substansi pembelajaran sebagaimana ditetapkan dalam kurikulum (Kompetensi Dasar) pada setiap materi pelajaran dengan proses pembimbingan kepada siswa. Jadi kompetensi profesional menjadi syarat utama bagi guru agar memiliki pengetahuan yang memadai terkait dengan bidang studi atau materi bahasan yang akan disampaikan kepada siswa, disamping juga harus dibarengi dengan kompetensi pedagogik, sebagimana dinyatakan oleh Suhandani \& Kartawinata (2014) 
bahwa dengan memiliki kompetensi profesional yang memadai maka penguasaan materi pembelajaran sesorang guru menjadi luas dan mendalam sehingga memungkinkan guru yang bersangkutan dapat membimbing siswa mencapai standar kompetensi sebagaimana telah digariskan dalam Standar Nasional Pendidikan. Guna mencapai tujuan tersebut seorang guru harus memahami dan menguasai materi ajar yang telah digariskan dalam kurikulum, memahami struktur materi pelajaran, menguasai konsep dan metode keilmuan yang koheren dengan materi ajar, memahami keterkaitan konsepsi antar mata pelajaran yang terkait, serta mengimplementasikan konsep-konsep keilmuan tersebut dalam kehidupan sehari-hari.

Kompetensi profesional merupakan salah satu aspek kompetensi yang harus dimiliki oleh guru berupa penguasaan materi pembelajaran secara luas dan mendalam. Kompetensi profesional tersebut dipengaruhi oleh beberapa faktor. Hasil penelitian Caraka \& Ika (2016) mengidentifikasikan delapan faktor-faktor yang mempengaruhi kompetensi profesional guru, meliputi: 1) Pendidikan dan pelatihan (Diklat), 2) kualifikasi akademik (latar belakang pendidikan), 3) supervisi akademik, 4) kepemimpinan kepala sekolah, 5) motivasi, 6) kesejahteraan atau kompensasi, 7) etos kerja, dan 8) kemampuan memanfaatkan teknologi informasi.

Pengertian Diklat (training) sebagaimana dinyatakan oleh Mangkunegara (2013) adalah proses pendidikan dalam durasi waktu relatif pendek dengan menerapkan prosedur sistematis dan terorganisir. Para pegawai managerial dalam diklat ini mempelajari pengetahuan konseptual dan teoritis guna mencapai tujuan umum yang telah ditentukan. Dengan demikian dapat disimpulkan tujuan diklat adalah meningkatkan pengetahuan dan keterampilan teknis bagi pegawai pelaksana.

Pendidikan dan pelatihan (diklat), menurut Siregar (2018) menempati posisi penting dalam perspektif manajemen strategis. Hal ini dikarenakan diklat akan membentuk nilai tambah bagi peningkatan kualitas (kompetensi) sumber daya manusia. Lebih lanjut Siregar menyatakan bahwa pada dasarnya pelatihan merupakan sebuah proses untuk meningkatkan profesi karyawan. Proses diklat secara sistematis dan strategis yang dapat meningkatkan profesionalisme individu dilaksanakan melalui beberapa komponen, meliputi: (1) menentukan tingkat skil yang dimiliki karyawan saat ini, (2) menyelekasi tempat yang fleksibel dan representatif, (3) menjadwalkan program kegiatan, (4) memilih metode pelatihan yang tepat, (5) mengumpulkan dan mengembangkan materi pelatihan, dan (6) melakukan evaluasi atas pelaksanaan diklat.

Berdasarkan Peraturan Menteri Pendayagunaan Aparatur Negara dan Reformasi Birokrasi Nomor 16 Tahun 2009 digariskan bahwa Pengembangan Keprofesian Berkelanjutan (PKB) merupakan pengembangan kompetensi bagi guru yang dilaksanakan sesuai dengan kebutuhan, bertahap, dan berkelanjutan untuk meningkatkan profesionalisme guru. Pendidikan dan pelatihan yang dilakukan secara sistematis guna memenuhi kebutuhan kekinian guru merupakan salah satu upaya untuk mengembangkan kompetensi guru yang pada gilirannya dapat meningkatkan profesionalitas guru.

Berdasarkan paparan secara teoritis tersebut dapat disimpulkan bahwa diklat bagi guru merupakan rangkaian kegiatan dalam upaya peningkatan kompetensi guru dalam 
melaksanakan tugas sebagai pendidik. Dengan Diklat diharapkan pengetahuan dan keterampilan seorang guru akan lebih meningkat sehingga berdampak pada peningkatan profesionalitas yang pada gilirannya akan meningkatkan kualitas pembelajaran sehingga prestasi yang dicapai oleh siswa juga semakin meningkat.

Kegiatan SPM yang pada hakekatnya juga merupakan kegiatan pendidikan dan pelatihan. Hasil kegiatan pendidikan dan pelatihan terdahulu, secara empiris membuktikan bahwa diklat dapat meningkatkan kompetensi profesional guru, baik pada aspek pengetahuan maupun keterampilannya (Muhammad Anas, Muchson, Sugiono, \& Rr. Forijati, 2021; M Anas, 2021b; M Anas, 2021a; Pratama, 2020; Mulyawan, 2012; Pramana, 2020). Berdasarkan paparan sebagaimana telah diuraikansebelumnya, maka kerangka pemikiran kegiatan PkM dalam bentuk SPM disajikan pada Gambar 1 berikut ini:

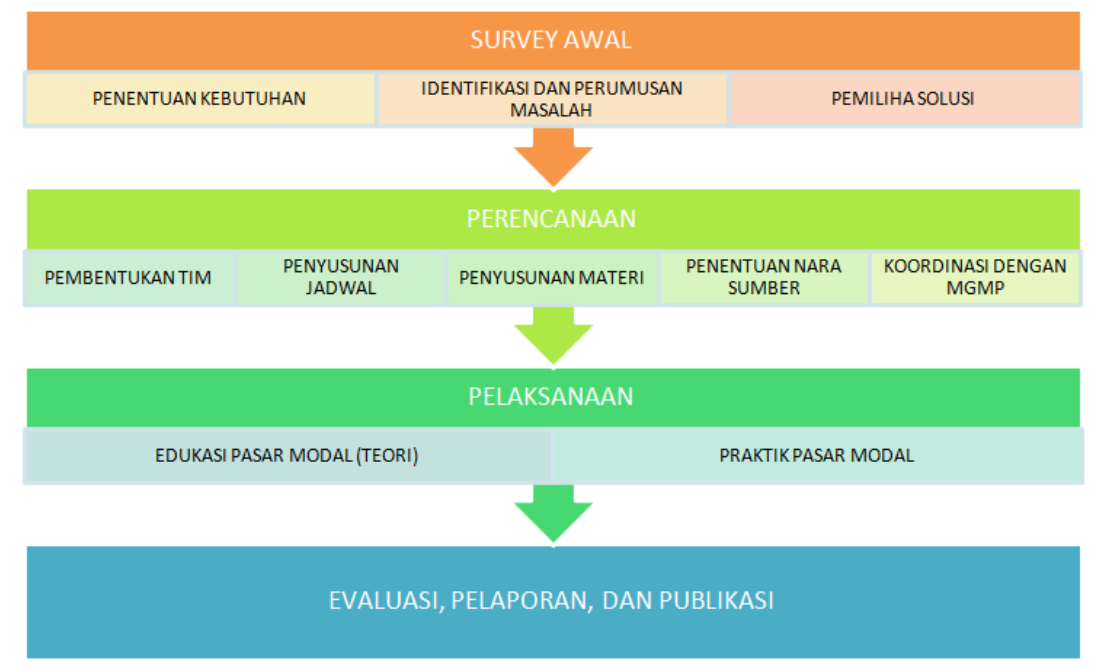

Gambar 1. Kerangka Pemecahan Masalah

Langkah-langkah kegiatan PkM dalam bentuk kegiatan SPM sebagai upaya meningkatkan kompetensi profesional guru ekonomi ini meliputi beberapa tahapan sebagai berikut:

1. Tahap Survey Pendahuluan

Survey pendahuluan dilakukan untuk keperluan analisis situasi. Situasi yang dihadapi oleh guru ekonomi menyangkut beberapa hal, meliputiI kebutuhan guru dalam upaya meningkatkan kompetensi profesional, tingkat literasi guru terkait dengan pasar modal, dan berbagai permasalahan yang dialami guru dalam pembelajaran dengan meteri ajar pasar modal.

2. Tahap Idenfikikasi dan Perumusan Masalah

Berbagai problematika yang dihadapi guru ekonomi sebagaimana hasil survey pendahuluan diidentifikasi dan dirumuskan secara jelas dan spesifik, agar solusi yang dipilih untuk mengatasi permasalah tersebut menjadi efektif. 


\section{Tahap Pemilihan Solusi}

Pemilihan solusi dalam menyikapi masalah yang terjadi didasarkan dengan mempertimbangakan ketersediaan sumber daya yang dimilki oleh Prodi Magister Pendidikan Ekonomi dengan memperhatikan prinsip efisiensi dan efektivias.

4. Tahap Perencanaan Kegiatan

Tahap perencanaan kegiatan mencakup beberapa hal, meliputi: pembentukan tim pelaksana kegiatan, penentuan jadwal kegiatan, penyusunan materi kegiatan, penentuan nara sumber untuk setiap materi kegiatan, dan koordinasi dengan ketua Musyawarah Guru Mata Pelajaran (MGMP) Ekonomi.

5. Tahap Pelaksanaan Kegiatan

Tahap pelaksanaan kegiatan merupakan kegiatan pemberian materi Sekolah Pasar modal kepada peserta sesuai dengan jadwal waktu dan materi yang telah disusun. Pelaksaan kegiatan SPM terdiri atas dua jenis materi, yaitu: teoritis (literasi pasar modal), dan praktik, yang terdiri atas: praktik pembukaan rekening dana nasabah, dan praktik transaksi pasar modal.

\section{Hasil dan Pembahasan}

Masyarakat sasaran dalam kegiatan ini merupakan peserta SPM yang dilaksanakan oleh Program Studi Magister Pendidikan Ekonomi Pascasarjana Universitas Nusantara PGRI Kediri sebagai bentuk kegiatan PkM. Jumlah peserta yang merupakan guru ekonomi di SMA/MA sebanyak 47 orang. Gambaran umum peserta SPM tampak sebagaimana Tabel 1 berikut ini.

Tabel 1. Jumlah Peserta Berdasarkan Jenis Kelamin dan Asal Daerah

\begin{tabular}{ccccc}
\hline \multirow{2}{*}{ Jenis Kelamin } & \multicolumn{3}{c}{ Asal Daerah } & Jumlah \\
& Kab. Kediri & Kota Kediri & Kab. Nganjuk & \\
\hline Pria & 5 & 3 & 1 & 9 \\
Wanita & 14 & 17 & 7 & 38 \\
Jumlah & 19 & 20 & 8 & 47 \\
\hline
\end{tabular}

Sumber: Data diolah

Tabel 1 menjelaskan bahwa dari jumlah peserta sebanyak 47 orang sebagian besar berasal dari Kabupaten Kediri, yaitu sebanyak 20 orang (42,55\%), sedangkan yang berasal dari Kabupaten Kediri sebanyak 19 orang (40,45\%) dan sebanyak 8 orang (17\%) berasal dari Kabupaten Nganjuk. Berdasarkan jenis kelamin, sebagian besar peserta adalah guru-guru ekonomi wanita, yaitu sebanyak 38 orang $(80,85 \%)$, dan guru ekonomi pria yang ikut kegiatan Sekolah Pasar Modal ini sebanyak 9 orang $(19,15 \%)$.

Berdasarkan aspek status sekolah asal peserta SPM, terdiri atas sekolah swasta dan sekolah negeri. Data status sekolah asal peserta disajikan pada Tabel 2 berikut ini. 
Jurnal Pengabdian Masyarakat As-Salam (JPMA)

Vol. 1 No. 2 Juli - Desember 2021: 79 - 90

M. Anas, Mochamad Muchson, Sugiono, Subagyo, Rr. Forijati, Nurin Eva Yanti

Tabel 2. Jumlah Peserta Berdasarkan Status Sekolah

\begin{tabular}{clccc}
\hline \multirow{2}{*}{ Status Sekolah } & \multicolumn{3}{c}{ Asal Daerah } & \multirow{2}{*}{ Jumlah } \\
& Kab. Kediri & Kota Kediri & Kab. Nganjuk & \\
\hline Negeri & 16 & 14 & 6 & 36 \\
Swasta & 3 & 6 & 2 & 11 \\
Jumlah & 19 & 20 & 8 & 47 \\
\hline
\end{tabular}

Sumber: Data diolah

Tabel 2 menjelaskan bahwa peserta SPM ini mayoritas diikuti oleh guru ekonomi pada sekolah negeri, yang mencapai 36 orang $(76,60 \%)$, dan sebanyak 11 orang $(23,40 \%)$ merupakan guru ekonomi pada sekolah swasta.

Berdasarkan kriteria asal sekolah, peserta SPM ini dikelompokkan menjadi dua asal sekolah, yaitu Sekolah Menengah Atas (SMA) dan Madrasah Aliyah (MA), sebagaimana disajikan pada Tabel 3 berikut ini:

Tabel 3. Jumlah Peserta Berdasarkan Asal Sekolah

\begin{tabular}{clccl}
\hline $\begin{array}{c}\text { Asal } \\
\text { Sekolah }\end{array}$ & Asal Daerah & & & Jumlah \\
\hline SMA & 18 & 17 & 8 & 43 \\
MA & 1 & 3 & - & 4 \\
Jumlah & 19 & 20 & 8 & 47 \\
\hline
\end{tabular}

Sumber: Data diolah

Tabel 3 menjelaskan bahwa SPM ini sebagian besar diikuti oleh peserta guru ekonomi pada SMA, yaitu sebanyak 43 orang (91,49\%), sedangkan guru ekonomi pada MA yang menjadi peserta kegiatan ini hanya sebanyak 4 orang $(8,51 \%)$.

Tingkat ketercapaian program pengabdian masyarakat diklasifikasikan menjadi dua, yaitu ketercapaian pelaksanaan kegiatan sekolah pasar modal dan tingkat ketercapaian kompetensi peserta setelah mengikuti kegiatan. Ketercapaian pelaksaan kegiatan PkM pasar modal diukur berdasarkan respon peserta atas pelaksanaan kegiatan SPM yang diikutinya. Data tentang respon peserta tersebut diperoleh melalui instrumen kuesioner yang diberikan kepada peserta ketika selesai mengikuti kegiatan PkM.

\section{Relevansi Materi Dengan Kebutuhan}

Respon peserta atas pelaksanaan kegiatan PkM menyatakan bahwa: materi yang diberikan pada SPM ini telah memiliki tingkat relevansi yang tinggi dengan kebutuhan peserta. Sebanyak 44 peserta (92\%) menyatakan bahwa materi yang diberikan pada SPM relevan dengan apa yang mereka perlukan, sehingga guru-guru ekonomi memiliki tambahan pengetahuan, pemahaman, dan keterampilan yang lebih memadai ketika menyapaikan materi Pasar Modal dalam pembelajaran ekonomi di sekolah.

\section{Cakupan Materi}

Respon peserta atas cakupan metari SPM menyatakan bahwa keluasan materi SPM memiliki cakupan yang sangat berarti. Hampir semua peserta (97\%) menyatakan bahwa materi SPM yang diberikan dalam kegiatan PkM ini memiliki cakupan yang luas, sehingga literasi pasar modal yang dimiliki peserta setelah mengikuti kegiatan ini bertambah secara signifikan. 


\section{Waktu Penyelenggaraan}

Ditinjau dari aspek waktu, penyelenggaraan kegiatan SPM sesuai dengan harapan peserta. Sebanyak 40 peserta $(45,1 \%)$ menyatakan bahwa pilihan waktu untuk melaksanakan kegiatan SPM adalah tepat, artinya sesuai dengan harapan mayoritas peserta, sehingga kegiatan SPM yang mereka ikuti tidak mengganggu tugas kewajiban di sekolah masing-masing. Namun demikian ada 2 (dua) atau sebanyak 4,3\% peserta yang menyatakan bahwa waktu penyelenggaraan kegiatan kini kurang tepat, karena adanya benturan waktu dengan tugas kewajiban mereka di sekolah.

\section{Layanan Jaringan}

Terkait dengan layanan jaringan internet (wifi) yang disediakan oleh penyelenggara, ada 10 peserta $(21,3 \%)$ yang merasakan sangat puas, sebagian besar peserta $(53,2 \%)$ menyatakan puas, dan sebanyak 10 peserta $(21,3 \%)$ menyatakan cukup puas dengan akses jaringan internet yang tersedia, dan ada 2 peserta $(4,3 \%)$ yang menyatakan tidak puas dengan ketersediaan jaringan internet yang disediakan oleh panitia penyelenggara kegiatan.

\section{Layanan Administrasi}

Penyelenggaraan kegiatan PkM SPM tidak terlepas dukungan layanan administrasi yang diberikan. Layanan administrasi tersebut meliputi: penyebarluasan informasi kepada guru, pendaftaran peserta, penyediaan presensi, materi pembelajaran, termasuk penyediaan sarana dan prasarana kegiatan. Terkait dengan layanan administrasi tersebut semua peserta menyatakan puas dengan layanan adminstrasi yang diberikan kepada peserta SPM.

\section{Ketercapaian Kompetensi}

Sebagaimana dipaparkan sebelumnya bahwa salah satu tujuan kegiatan PkM SPM ini adalah untuk meningkatkan kompetensi profesional peserta, yaitu guru ekonomi. Indikator kompetensi tersebut berupa pengetahuan dan pemahaman peserta terkait pasar modal. Intsrumen yang digunakan untuk mengetahui tingkat pengetahuan dan pemahaman peserta terkait pasar modal berupa soal berbentuk multiple choise yang didesain secara khusus untuk keperluan tersebut. Soal-soal tersebut diberikan kepada peserta pada waktu sebelum peserta mengikuti materi SPM (pre test) dan setelah mengikuti SPM (post test). Tingkat ketercapaian kompetensi peserta diukur dengan membandingkan antara capaian nilai jawaban sebelum dan setelah SPM.

Berikut ini disajikan hasil analisis data statistik terkait kompetensi professional guru ekonomi sebelum dan sesudah mengikuti kegiatan PkM Sekolah Pasar Modal.

Tabel 4. Capaian Kompetensi Sebelum Kegiatan

\begin{tabular}{rrrrrr}
\hline & & Frequency & Percent & Valid Percent & Cumulative Percent \\
\hline Valid & 45.00 & 1 & 2.1 & 2.1 & 2.1 \\
& 50.00 & 3 & 6.4 & 6.4 & 8.5 \\
& 55.00 & 5 & 10.6 & 10.6 & 19.1 \\
& 60.00 & 10 & 21.3 & 21.3 & 40.4 \\
& 65.00 & 8 & 17.0 & 17.0 & 57.4 \\
& 70.00 & 8 & 17.0 & 17.0 & 74.5
\end{tabular}


Jurnal Pengabdian Masyarakat As-Salam (JPMA)

Vol. 1 No. 2 Juli - Desember 2021: 79 - 90

M. Anas, Mochamad Muchson, Sugiono, Subagyo, Rr. Forijati, Nurin Eva Yanti

\begin{tabular}{lrrrr}
75.00 & 8 & 17.0 & 17.0 & 91.5 \\
80.00 & 4 & 8.5 & 8.5 & 100.0 \\
Total & 47 & 100.0 & 100.0 & \\
\hline
\end{tabular}

Sumber: Data statistik diolah

Tabel 5. Capaian Kompetensi Setelah Kegiatan

\begin{tabular}{rrrrrr}
\hline & Frequency & \multicolumn{2}{c}{ Percent } & Valid Percent & Cumulative Percent \\
\hline Valid & 75.00 & 4 & 8.5 & 8.5 & 8.5 \\
& 80.00 & 10 & 21.3 & 21.3 & 29.8 \\
& 85.00 & 10 & 21.3 & 21.3 & 51.1 \\
90.00 & 11 & 23.4 & 23.4 & 74.5 \\
95.00 & 5 & 10.6 & 10.6 & 85.1 \\
& 100.00 & 7 & 14.9 & 14.9 & 100.0 \\
& Total & 47 & 100.0 & 100.0 &
\end{tabular}

Sumber: Data statistik diolah

Capaian kompetensi maksimal guru sebelum mengikuti kegiatan PSM sebagaimana ditunjukkkan Tabel 4 adalah dengan nilai 8 , bahkan ada 1 orang peserta yang mendapatkan nilai 45. Sebagian peserta, sebanyak 5 orang $(21,3 \%)$ mendapatkan nilai 60. Sedangkan capaian kompetensi setelah dilaksanakan kegiatan SPM sebagaimana ditunjukkan Tabel 5 menjadi jauh lebih baik. Nilai terendah yang dicapai oleh peserta adalah 75 dan bahkan nilai tertinggi mencapai angka 100. Jumlah peserta yang mendapatkan nilai 100 mencapai 7 orang peserta $(14,9 \%)$.

Tabel 6. Capaian Kompetensi Sebelum dan Setelah Kegiatan

\begin{tabular}{lcc}
\hline \multicolumn{1}{c}{ Keterangan } & Sebelum & Setelah \\
\hline Mean & 65,31 & 87,55 \\
Median & 65,00 & 85,00 \\
Mode & 60,00 & 90,00 \\
Stand. Deviation & 8,99 & 7,65 \\
Variance & 80,87 & 58,55 \\
Minimum & 45,00 & 75,00 \\
Maximum & 80,00 & 100,00 \\
Sum & $3.070,00$ & $4.115,00$ \\
\hline
\end{tabular}

Sumber: Data statistik diolah

Tabel 6 menunjukkan bahwa nilai rata-rata yang dicapai oleh peserta kegiatan PSM setelah mengikuti kegiatan meningkat menjadi 87,55 dibandingkan dengan sebelum mengikuti kegiatan, dimana nilai rata-ratanya sebesar 65,32. Sebelum mengikuti kegiatan nilai terendah peserta adalah 45 dan setelah mengkuti kegiatan nilai terendah yang diperoleh peserta sebesar 75. Bahkan, peserta mampu mencapai nilai maksimal yaitu 100 setelah mereka mengikuti kegiatan, padahal sebelum dilaksanakan kegiatan nilai maksimum yang dicapai peserta sebesar 80. Dengan demikian dapat disimpulkan bahwa kegiatan PkM SPM ini dapat meningkatkan kompetensi profesional guru ekonomi yang 
ditunjukkan dengan semakin meningkatnya pengetahuan dan pemahaman pasar modal bagi guru ekonomi di Kediri dan sekitarnya.

Pembuktian secara statistik intensitas ada tidaknya perbedaan kompetensi profesional guru ekonomi antara sebelum dan setelah mengikuti kegiatan PkM SPM dilakukan dengan uji beda berupa Uji Paired Sample T (Paired Sample T Test) berbantuan aplikasi SPSS Versi 23. Hasil pengujian secara statistik tampak pada Tabel 7 berikut ini:

Tabel 7. Paired Sample Correlations

\begin{tabular}{llccc}
\hline & & N & Correlation & Sig. \\
\hline Pair 1 & Pretest \& posttest & 47 & .714 & .000 \\
\hline
\end{tabular}

Sumber: Data statistik diolah

Pengujian secara statistik guna menguji ada tidaknya perbedaan tingkat kompetensi yang dicapai oleh peserta kegiatan PkM SPM dilakukan dengan menggunakan uji dua sisi dengan tingkat signifikansi $(\alpha) 5 \%$ atau sebesar setengah dari 5\% $=2,5 \%$ atau 0,025 . Hasil uji statistik sebagaimana Tabel 7 menunjukkan bahwa kelompok Paired-Sample Correlations menghasilkan angka Sig. 0,00. Atau dengan kata lain angka $\mathrm{P}_{\text {value }}(\mathrm{sig})<$ 0,025 . Dengan demikian dapat disimpulkan bahwa terdapat perbedaan yang signifikan capaian kompetensi profesional guru ekonomi antara sebelum dan setelah mengikuti kegiatan PkM Sekolah Pasar Modal.

\section{Kesimpulan}

Berdasarkan hasil analisis data sebagaimana dipaparkan sebelumnya, dapat disimpulkan bahwa kegiatan PkM berupa Sekolah Pasar Modal merupakan solusi yang efektif diterapkan untuk meningkatkan kompetensi profesional guru ekonomi terkait dengan aspek pengetahuan, pemahaman dan keterampilan tentang pasar modal, yang merupakan salah satu materi yang harus dipelajari dalam mata pelajaran ekonomi di tingkat Sekolah Menengah Atas (SMA) dan sederajat. Peningkatan kompetensi guru tersebut ditunjukkan dengan beberapa indikator sebagai berikut: (1) Nilai rata-rata yang dicapai oleh peserta kegiatan SPM setelah mengikuti kegiatan meningkat menjadi 87,55 dibandingkan dengan sebelum mengikuti kegiatan yaitu sebesar 65,32, (2) Sebelum mengikuti kegiatan nilai terendah peserta adalah 45 dan setelah mengkuti kegiatan nilai terendah yang diperoleh peserta sebesar 75, (3) Nilai maksimal setelah mengikuti kegiatan mencapai angka 100, padahal sebelum dilaksanakan kegiatan nilai maksimum yang dicapai peserta sebesar 80, (4) Terdapat perbedaan yang signifikan capaian kompetensi profesional guru ekonomi antara sebelum dan setelah mengikuti kegiatan PkM Sekolah Pasar Modal.

Metode pendidikan dan pelatihan merupakan kegiatan yang efektif untuk meningkatkan pengetahuan dan pemahaman seseorang terhadap suatu materi (konten) tertentu. Oleh karenanya untuk meningkatkan kompetensi profesional guru, khususnya guru ekonomi, dipandang perlu untuk meningkatkan kerjasama kolaboratif dan sinergis antara Program Studi Magister Pendidikan Ekonomi dengan pihak terkait sebagai implementasi tridharma perguruan tinggi dalam bidang PkM dalam bentuk kegiatan 
Jurnal Pengabdian Masyarakat As-Salam (JPMA)

Vol. 1 No. 2 Juli - Desember 2021: 79 - 90

M. Anas, Mochamad Muchson, Sugiono, Subagyo, Rr. Forijati, Nurin Eva Yanti

serupa, sehingga kemanfaatan program ini dapat dirasakan secara berkelanjutan oleh berbagai pihak.

\section{Ucapan Terima Kasih}

Ucapan terima kasih kami disampaikan kepada: Rektor Universitas Nusantara PGRI Kediri beserta jajaran pimpinan universitas, Ketua LPPM, Direktur Pascasarjana, anggota Tim PkM, Ketua MGMP Ekonomi SMA dan MA Kabupaten Kediri dan Kota Kediri, dan pengelola Galeri Bursa Efek Indonesia Kampus Universitas Nusantara PGRI Kediri atas kerjasamanya sehingga kegiatan $\mathrm{PkM}$ ini dapat dilaksanakan tanpa ada hambatan yang berarti. Pendanaan kegiatan PkM ini berasal dari Dana Stimulus PkM pada Lembaga Penelitian dan Pengabdian Masyarakat (LPPM) Universitas Nusantara PGRI Kediri, disertai harapan semoga kegiatan ini dapat memberikan manfaat bagi semua pihak.

\section{Daftar Pustaka}

Anas, M. (2021a). Pengembangan Bahan Ajar Berbasis Kasus: Menuju Inovasi Pembelajaran Mata Kuliah Kajian Makro Ekonomi. SOSIOEDUKASI Jurnal Ilmiah Ilmu Pendidikan Dan Sosial, 10(1), 113-124. doi: https://doi.org/10.36526/sosioedukasi.v10i1

Anas, M. (2021b). Peningkatan Kualitas Pembelajaran Mata Kuliah Akuntansi Biaya Berbasis Lesson Study. Pandawa: Jurnal Pendidikan Dan Dakwah, 3(2), 244-258. doi: https://doi.org/10.36088/pandawa.v3i2.1185

Anas, M., Muchson, M., Sugiono, S., \& Rr. Forijati. (2021). Pengembangan Kemampuan Guru Ekonomi di Kediri Melalui Kegiatan Pelatihan Asesmen Kompetensi Minimum (AKM). Rengganis Jurnal Pengabdian Masyarakat, 1(1), 48-57. doi: https://doi.org/10.29303/rengganis.v1i1.28

Boyatzis, R. E. (2008). Competencies in the 21st century. Journal of Management Development, 27(1), 5-12. doi: https://doi.org/10.1108/02621710810840730

Caraka, P., \& Ika, M. (2016). Strategi LPTK Dalam Pengembangan Kompetensi Pedagogik Calon Guru. Jurnal Pendidikan (Teori Dan Praktik), 1(2), 96-106. http://eprints.uad.ac.id/id/eprint/6476

Kemendikbud. (2017). Buku Panduan Implementasi Kecakapan Abad 21 Kurikulum 2013 Di SMA. Jakarta: Dit. PSMA Ditjen Pendidikan Dasar dan Menengah.

Mangkunegara. (2013). Perencanaan dan Pengembangan Sumber Daya Manusia. Bandung: Penerbit Refika Aditama.

Mulyawan, B. (2012). Pengaruh Pengalaman dalam Pelatihan terhadap Peningkatan Kompetensi Profesional Guru. Media Kumunikasi FPIPS, 11(1), 45-65.

Retrieved from https://ejournal.undiksha.ac.id/index.php/MKFIS/article/view/453

Pemerintah RI. (n.d.). Undang-Undang Nomor 20 Tahun 2003 tentang Sistem Pendidikan Nasional.

Pramana, C. A. (2020). Kontribusi Instruktur dan Pelatihan Terhadap Pengembangan Kreativitas Peserta Pelatihan di UPT Pelatihan Kerja Tulungagung. Jupeko (Jurnal Penididkan Ekonomi), 5(2), 20-30. doi: https://doi.org/Prefix 31763

Pratama. (2020). Pengaruh Pelatihan Terhadap Kompetensi Pedagogik Guru 
matematika2020Jurnal Cendekia: Jurnal Pendidikan Matematika, 4(1), 278-285. doi: https://doi.org/10.31004/cendekia.v4i1.207

Rakib. (2016). PENGARUH PELATIHAN DAN PENGALAMAN MENGAJAR TERHADAP PROFESIONALITAS GURU (Studi pada Guru IPS Terpadu yang Memiliki Latar Belakang Pendidikan dalam Bidang Pendidikan Ekonomi), Ad'ministrare, 3(2), 137-148.

doi: https://doi.org/10.26858/ja.v3i2.2574

Siregar, E. (2018). Faktor-Faktor Yang Mempengaruhi Manajemen Pendidikan Dan Pelatihan (Diklat) Dalam Upaya Pengembangan Sumber Daya Manusia (SDM). Jurnal Dinamika Pendidikan, 11(2), 153-166. doi: https://doi.org/10.51212/jdp.v11i2.812

Spenser, L. M., \& Spenser, S. M. (1993). Competence at work: Models for superior performance. New York: John Wolfley and Sons Inc.

Suhandani, D., \& Kartawinata, J. (2014). Identifikasi Kompetensi Guru Sebagai Cerminan Profesionalisme Tenaga Pendidik Di Kabupaten Sumedang (Kajian Pada Kompetensi Pedagogik). Mimbar Sekolah Dasar, 1(2) 128-141.

doi: https://doi.org/10.53400/mimbar-sd.v1i2.874 